DOI: https://doi.org/10.24144/2409-6857.2019.1(53).146-153

УДК 336.71:336.73

Варцаба В.І., Заславська О.I.

\title{
ІНТЕГРАЦІЯ БАНКІВ ТА НЕБАНКІВСЬКИХ КРЕДИТНИХ УСТАНОВ В УКРАЇНІ: РИЗИКИ ТА ПРОБЛЕМИ ВЗАСМОДІї
}

\begin{abstract}
У статті розглянуто питання інтеграчіi банків та небанківських кредитних установ, а також досліджено проблемні та дискусійні положення функиіонування інтегрованих фінансових посередників. Окреслено фінансові мотиви до взаємодії банків та небанківських кредитних установ. Подано систему ризиків інтегрованих фінансових посередників. Здійснено аналіз активів украӥнських банків та небанківських кредитних установ. Дано оцінку діяльності фінансових конгломератів групи "allfinance» 3 вітчизняним капіталом. Виділено основні проблеми, з якими стикаються інтегровані фінансові посередники в Україні.
\end{abstract}

Ключові слова: банк, небанківська кредитна установа, фінансові посередники, інтеграчія, ризики інтегрованих фінансових посередників, активи.

Постановка проблеми. Сучасне світове господарство функціонує в умовах стрімкого розвитку фінансових ринків. Практика свідчить, що діяльність добре розвинених фінансових посередників i постійне розширення та вдосконалення їхніх послуг неодмінно сприяють підвищенню продуктивності економік країн. Так, посередники на фінансових ринках здійснюють широкомасштабне інвестування економіки за рахунок переміщення тимчасово вільних грошових коштів від тих економічних суб'єктів, які мають їх надлишок i не можуть його ефективно використати, до тих, хто має нагальну потребу у грошах. Водночас високий рівень конкуренції призводить до того, що структура фінансових посередників змінюється від спеціалізованих до потужних інтегрованих фінансових інститутів. При цьому відбувається зближення різних видів посередництва та виникнення комплексних продуктів.

Аналіз останніх досліджень і публікацій. Проблемі вивчення призначення та економічної сутності фінансового посередництва, а також особливостей діяльності фінансових посередників присвячено велику кількість наукових праць. Дослідження даного питання проводили як зарубіжні, так і українські вчені.

(C) Варцаба B.I., д.е.н., професор, завідувач кафедри фінансів і банківської справи, ДВНЗ «Ужгородський національний університет», м. Ужгород, тел.: +380505026505, e-mail: vira.vartsaba@gmail.com

Заславська О.І., к.е.н., доцент кафедри фінансів і банківської справи, ДВНЗ «Ужгородський національний університет», м. Ужгород, тел.: +380501011695, e-mail: olga.zaslavska@uzhnu.edu.ua
Зокрема, йдеться про таких науковців, як: Дж. Ван Хорн, 3. Боді, Е. Долан, Ф. Мишкін тощо. Значний внесок у розробку теоретико-методичних основ функціонування суб’єктів кредитної системи у контексті їхньої взаємодії та інтеграції зробили такі українські науковці, як: Васильєва Т. А., Єпіфанов А. О., Єрмошенко А. М., Кльоба Л. Г., Кремень В. М., Лєонов С. В., Лютий І. О., Реверчук С. К., Сисоєва Л. Ю., Школьник І. О. та інші.

Формулювання цілей статті. Метою статті $\epsilon$ узагальнення теоретико-методологічних засад та обгрунтування наукових підходів щодо інтеграції банків та небанківських кредитних установ, а також дослідження проблемних i дискусійних положень функціонування інтегрованих фінансових посередників в Україні.

Для реалізації поставленої мети використано загальнонаукові та спеціальні методи наукового пізнання. Зокрема, дедукція, індукція, метод групування та графічний метод. За їх допомогою визначено сутність, форми та ризики взаємодії банків та небанківських фінансово-кредитних установ. Також було застосовано порівняння, методи аналізу та синтезу даних, за допомогою яких дано оцінку банківського та небанківського секторів економіки України, стану діяльності вітчизняних інтегрованих фінансових посередників.

Опис основного матеріалу дослідження. Найважливішими характеристиками сучасного фінансово-кредитного бізнесу в умовах фінансової глобалізації є посилення дерегуляції та конкуренції, збільшення спектру ризиків та зростання їхніх рівнів, упровадження фінансових інновацій, реінжиніринг бізнес-процесів. Зазначені аспекти спонукають банківські та небанківські кредитні установи до взаємного бізнесу та консолідації капіталів. Значною мірою 
така взаємодія є об’єктивним явищем, оскільки, завдяки спеціалізації та економії на масштабах інвестицій, фінансові посередники здатні зменшувати транзакційні витрати. Загалом серед цілей створення інтегрованих фінансових посередників варто назвати такі, як: максимізація прибутку, мінімізація ризиків та витрат, збільшення ринкової ніші, формування іміджу надійного мультифункціонального фінансового партнера.

Основними причинами для взаємодії між фінансовими посередниками є:

- обмеженість ресурсів у одних учасників ринку та їх наявність у інших;

- потреба переливу капіталу з одного сектору в інший;

- потреба в отриманні додаткового доходу від здійснення суміжних операцій;

- наявність досвіду і технологічного оснащення у фінансових посередників для здійснення інвестицій та вигідного розміщення коштів;

- потреба економіки у взаємодії фінансових посередників;

- розвиток виробництва та товарно-грошових відносин, необхідність опосередковувати відтворювальний процес.

На основі вивчення та систематизації наукових напрацювань із даного питання $[1 ; 2 ; 3 ; 4 ; 17 ; 21]$ пропонуємо розглядати фінансові мотиви до взаємодії банків та небанківських кредитних установ за такими аспектами:

1. Мінімізація витрат. Ефективний розподіл ресурсів інтегрованого фінансового посередника за рахунок зменшення витрат унаслідок об'єднання та економії на взаємодоповнюючих ресурсах, скорочення адміністративних, інформаційних i маркетингових витрат, спільного використання клієнтської бази, технологій, каналів збуту тощо.

2. Максимізація доходів. Підвищення продуктивності банківської та небанківської діяльності за рахунок збільшення процентних та комісійних доходів унаслідок розширення спеціалізації, поліпшення маркетингу та посилення позиції на ринку.

3. Оптимізація управління. Якісне та ефективне управління ресурсною базою за наявності єдиної управлінської вертикалі, спільного власника (-ів), ведення уніфікованої цінової, збутової, товарної та комунікаційної політики, а також підвищення ефективності управління ліквідністю окремих учасників інтегрованої структури.

4. Посилення конкурентоспроможності. Посилення конкурентної позиції на ринку та пожвавлення ринкової кон'юнктури за рахунок створення єдиного бренду, стандартів обслуговування, інтеграції бізнеспроцесів, універсалізації та розширення спектру послуг

5. Підвищення інвестиційної привабливості. Зростання інвестиційної привабливості інтегрованого фінансового посередника за рахунок акумуляції фінансових ресурсів, диверсифікації вкладень, підвищення ринкової капіталізації та підвищення норми прибутковості .

6. Оптимізація ризиків. Зменшення рівня ризиків за рахунок об'єднання технологій ідентифікації, оцінки, управління ними та зростання надійності всіх спільних фінансових операцій за стабільних умов функціонування банків i небанківських кредитних установ.

Таким чином, розширення діяльності фінансових посередників шляхом інтеграції спрямовано на максимізацію прибутку, мінімізацію ризиків та розширення ринкової ніші, оскільки основою їх створення є диверсифікація, яка полягає у якомога ширшому охопленні всіх сегментів фінансового ринку. Водночас поряд із багатьма позитивними ефектами спільного функціонування взаємодія банків та небанківських установ може призводити до посилення ризикової складової у діяльності інтегрованого фінансового посередника. Фінансові конгломерати $є$ великими системними компаніями, які характеризуються внутрішнім переплетінням діяльності кількох фінансових посередників, що зумовлює появу нових специфічних ризиків.

На рис. 1 представлено систему ризиків інтегрованих фінансових посередників. традиційно найбільш небезпечні ризики інтегрованих фінансових посередників кредитний, ринковий та операційний - пов'язані зі здійсненням операцій на фінансовому ринку.

Відомо, що кредитний ризик полягає у можливості невиконання позичальником зобов'язань перед кредитною установою. Саме тому, у фінансовому конгломераті цей вид ризику найбільше сконцентровано у банківських установах. Ринковий ризик пов'язано 3 можливістю несприятливої зміни ринкової вартості фінансових інструментів, курсів валют чи відсоткових ставок. Тому ключем до його оцінки є виділення таких підвидів, як фондовий, валютний та відсотковий ризики. Фондовий ризик означає можливість виникнення фінансових втрат внаслідок зміни ринкових цін на цінні папери. . Валютний ризик означає небезпеку понесення 


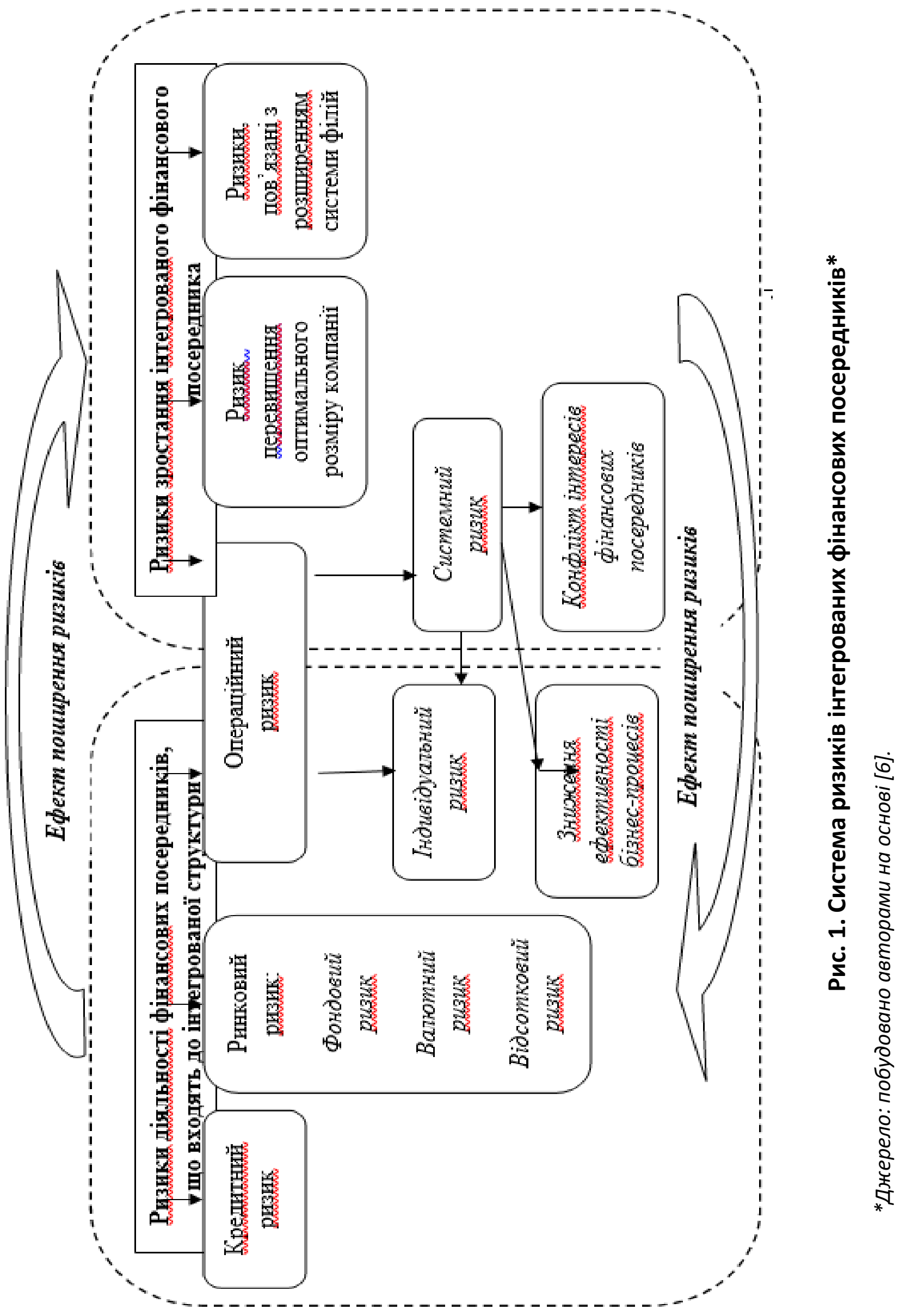


збитків, пов'язаних зі зміною курсу однієї іноземної валюти щодо іншої при проведенні операцій. Відсотковий ризик пов'язано зі зміною характеру динаміки відсоткових ставок [20]. Операційний ризик - це ймовірність виникнення збитків внаслідок недоліків чи помилок у внутрішніх процесах корпоративних структур, у діях співробітників та інших осіб, у роботі інформаційних систем, або внаслідок зовнішнього впливу [18].

У межах інтегрованої фінансової установи гостро стоїть проблема ідентифікації та уникнення саме операційного ризику, адже наявність значного обсягу операцій складніше проконтролювати. Тому, операційний ризик розглядають у контексті індивідуальної та системної форм прояву. Індивідуальний операційний ризик проявляється у діяльності кожної фінансово-кредитної установи, що входить до складу інтегрованого фінансового посередника. Системний операційний ризик може проявлятися у зниженні ефективності бізнеспроцесів та конфлікті інтересів серед окремих фінансових посередників. Так, у великому фінансовому конгломераті може виникнути проблема реалізації спільних рішень, координації розвитку інтегрованого фінансового посередника, ускладнюється розподіл повноважень і відповідальності між керівними органами [9].

Як свідчить світовий досвід, фінансові конгломерати здійснюють діяльність відповідно до стратегії постійного зростання. Це призводить до виникнення у їх діяльності ризиків надмірного розвитку, а саме: ризиків перевищення оптимального розміру компанії та ризиків, пов'язаних із розширенням мережі філій i представництв. Ризик перевищення оптимального розміру компанії виникає i особливо загострюється у процесі діяльності фінансових конгломератів, які $\epsilon$ транснаціональними корпораціями, адже постійне розширення ними мережі своїх представництв і фінансова конвергенція мають певні межі. Ризики, пов'язані 3 розширенням системи філій i представництв, виникають внаслідок того, що діяльність фінансових конгломератів передбачає побудову глобальної мережі надання фінансових послуг [5].

Отже, ризикова діяльність окремих установ інтегрованого фінансового посередника породжує ризики для всіх учасників такого об'єднання. Тобто існує можливість виникнення ефекту поширення ризиків, пов'язаного зі взаємними зобов'язаннями фінансових посередників та взаємною участю у капіталі. Наявність взаємних зобов' язань між фінансовими посередниками призводить до того, що вони наражаються на ризик, не властивий для їхнього конкретного сектору бізнесу [8].

Окрім того, на діяльність інтегрованих фінансових посередників, як і інших фінансових посередників, впливають ризики, пов'язані із зовнішнім середовищем. Ці ризики виникають внаслідок змін законодавчого забезпечення, заходів державного регулювання, економічної і політичної ситуації тощо. Таким чином, інтеграційні засади діяльності фінансових конгломератів i значні обсяги внутрішніх міжсекторальних фінансових операцій зумовлюють появу нових видів ризиків, а фінансово-кредитні установи, що входять до їхнього складу, підлягають додатковому фінансовому нагляду.

Нині в Україні має місце тенденція до формування банкоцентричної моделі кредитного ринку, про що свідчить значне переважання активів банківських установ із-поміж загальних активів інших посередників, здатних акумулювати тимчасово вільні ресурси у країні 3 метою забезпечення потреб економіки в інвестиціях. У системі відтворення української економіки банківські інвестиції відіграють важливу роль щодо відновлення і збільшення економічного потенціалу, а, отже, у забезпеченні високих темпів економічного зростання (рис. 2).

Як бачимо, незважаючи на велику кількість діючих установ небанківського типу (понад 2000 щороку), банківська діяльність в Україні $€$ переважаючою. Так, обсяги активів банків протягом усього аналізованого періоду перевищували аналогічний показник небанківського сектора у 8-10 разів.

Досягнення макрофінансової рівноваги для ефективної реалізації програм інституційного та інвестиційного розвитку країни потребує підвищення рівня концентрації інвестиційного капіталу. Питання створення інтеграційних об'єднань інвестиційної спрямованості особливо гостро постало в умовах розгортання кризових явищ в економіці країни, коли провідні фінансові установи відчули кризу ліквідності, внаслідок якої відбулося суттєве скорочення, а у багатьох випадках - і згортання інвестиційної діяльності.

В Україні у рамках інтегрованого фінансового посередництва відбувається співпраця установ у 


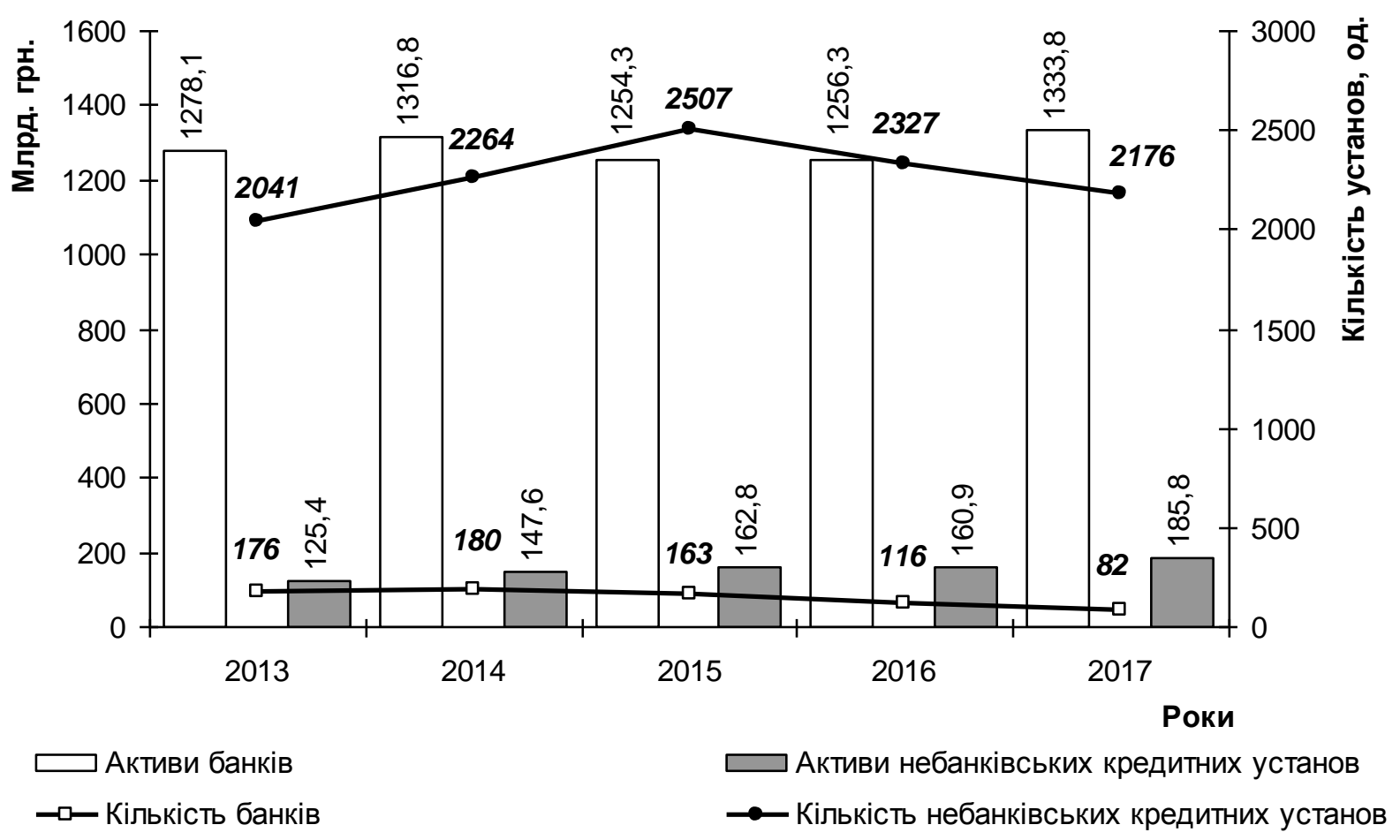

Рис. 2. Обсяги активів банків та небанківських кредитних установ у 2013-2017 рр., млрд. грн.*

*Джерело: побудовано авторами на основі [10; 11]

формі allfinance, де материнською компанією являється банк. На рис. 3 подано дані щодо обсягів активів найбільших українських фінансових конгломератів у 2017 році.
ПАТ КБ

«Приватбанк»;

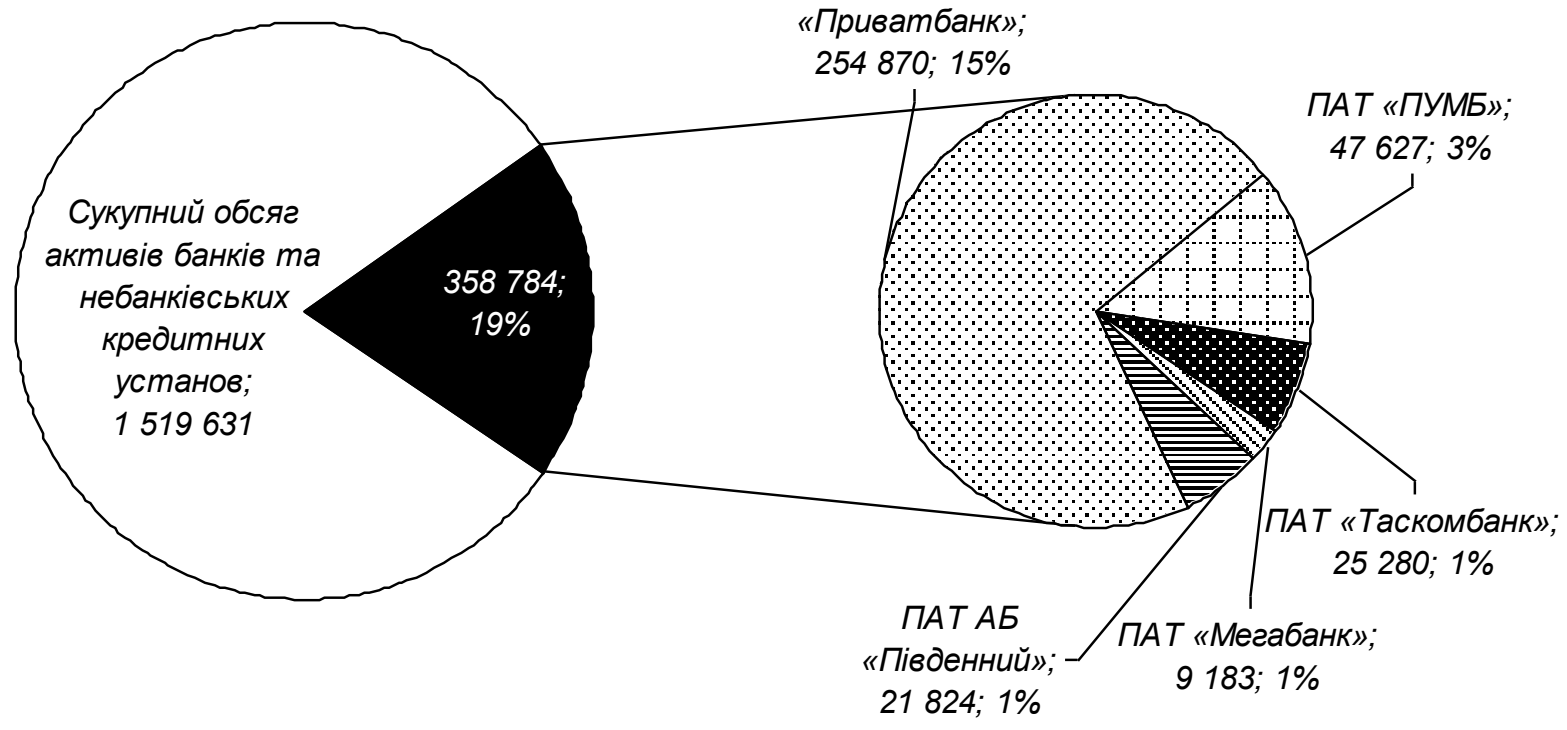

Рис. 3. Обсяги активів найбільших фінансових конгломератів групи «allfinance» 3 вітчизняним капіталом в Україні у 2017 році, млн. грн.* 


\section{*Джерело: побудовано авторами на основі [10; 11; 12; 13; 14; 15; 16$]$}

Варто підкреслити загальні переваги для банку від створення фінансового конгломерату, що передбачають можливість збільшити доходи, розширити інфраструктуру та отримати партнера, вкладника i позичальника в одній особі на довготривалий термін. 3 іншого боку, банк надає небанківській установі фінансову підтримку, може здійснювати юридичний супровід, розрахунково-касове обслуговування та перевіряти потенційних клієнтів.

Загалом в Україні існує досить незначна кількість інтегрованих фінансових посередників, створених саме на основі українського капіталу. Думки фахівців щодо майбутнього таких структур, створених внаслідок взаємодії банків із небанківськими фінансовими посередниками $\epsilon$ суперечливими. Аналіз досвіду становлення та функціонування вітчизняних інтегрованих фінансових посередників дає можливість виділити основні проблеми, 3 якими вони стикаються.

По-перше, це проблеми технологічного характеру, які нерідко стають на заваді розвитку інтегрованої фінансової установи. Швидке надання фінансових послуг потребує досконалих технологічних рішень, які, у свою чергу, коштують досить дорого. Всі технологічні процеси в об'єднаній структурі мають розроблятися 3 акцентом на cross selling (перехресний продаж) i обов'язкове навчання персоналу [7].

По-друге, це проблеми, пов'язані 3 недосконалістю документообігу, що перетворюють фінансово-кредитну установу на бюрократичну контору. До прикладу, здійснення операцій українськими банками, як правило, супроводжується складанням кількох документів, які повинні підписати різні відповідальні особи. Такий підхід помітно уповільнюе процес обслуговування клієнтів, спричиняє збільшення кількості функціональних працівників, що суперечить ідеї інтегрованої фінансової установи.

По-третє, це кадрові проблеми. Успішність кожної фінустанови залежить не лише від розміру iii капіталу, наявності розробленої стратегії, кількості філій чи особливостей продуктового асортименту, але й від уміння продавати специфічний продукт. Саме тому успішний працівник кредитної установи повинен бути не просто хорошим економістом, а людиною, здатною знаходити з кожним клієнтом спільну мову [9].

По-четверте, суттєво стримують розвиток фінансових супермаркетів і проблеми психологічного характеру. Річ у тім, що українці поки що не сприймають кредитну установу як фінансового радника та помічника. $\mathrm{y}$ співвітчизників поки що немає розуміння того, що у банках можуть запропонувати повний спектр фінансових послуг (окрім депозитнокредитних операцій та прийому комунальних платежів). Саме через це і попит на такий продуктовий ряд не вельми високий. Почасти у цьому винні самі банкіри, які здебільшого пропонують послуги у такому стандартному наборі, який далеко не завжди відповідає вимогам часу.

По-п'яте, наявні проблеми правового поля, обумовлені тим, що сьогодні всі види фінансових посередників підпорядковуються чималій кількості різних регулюючих органів: банки Національному банку України; страхові компанії, недержавні пенсійні фонди, лізингові фірми та інші небанківські структури - Національній комісії, що здійснює державне регулювання у сфері ринків фінансових послуг; компанії 3 управління активами - Національній комісії 3 цінних паперів та фондового ринку. Досить часто різночитання по одному і тому ж самому питанню розвитку фінансових посередників не дозволяє створювати спільну послугу, створює труднощі при оподаткуванні, а, відповідно, перешкоджає інтеграції банків i небанківських фінансових посередників [19].

Висновки i перспективи подальших досліджень. Інтеграція фінансових посередників несе у собі чимало проблем, які потребують вирішення. Це, насамперед, пов'язано із різноманіттям фінансово-кредитних установ та їхніми унікальними особливостями діяльності. Кожна зі складових розвитку кредитної сфери має свої специфічні шляхи вирішення проблем, що підтверджує необхідність проведення відповідних досліджень у сфері розроблення механізмів для забезпечення розвитку економіки України. Подолання зазначених проблем потребує неабияких зусиль, адже необхідно поновому подивитися на суть послуг банків та небанківських кредитних установ, a, отже, перейти на вищий рівень фінансової культури. Функціонування зазначених ринків повинно стати важливим джерелом розвитку реального сектора економіки, забезпечуючи тісний зв'язок між суб'єктами господарювання, населенням i фінансово-кредитними установами. 


\section{ПЕРЕЛІК ВИКОРИСТАНИХ ДЖЕРЕЛ}

1. Benoist G. Bancassurance: The New Challenges / G. Benoist // The Geneva Papers on Risk and Insurance. - 2002. Vol. 27, №3. - P. 295-303.

2. Okeahalam C. Does Bancassurance Reduce the Price of Financial Service Products / C. Okeahalam // Journal of Financial Services Research. - 2008. - № 33. - P. 147-162.

3. Paige F. L. Bidder returns in bancassurance mergers: Is there evidence of synergy? / Fields L. Paige, Fraser R. Donald, Kolari W. James // Journal of Banking \& Finance. - 2007. - № 31. - P. 3646-3662.

4. Багмет К. В. Банківсько-страхова інтеграція в забезпеченні розвитку фінансового сектора економіки: дис. на здобуття наук. ступеня канд. економ. наук: спец 08. 00. 08 - гроші, фінанси і кредит/ К. В. Багмет; ДВНЗ «УАБС НБУ». - Суми, 2012. - 267 с.

5. Білорус О. Г., Гаврилюк О. В. Фінансова глобалізація: парадигмальні зрушення й ризики // Фінанси України. - 2013. - № 7. - С. 7-17.

6. Інтеграційні процеси на фінансовому ринку України: монографія / за заг. редакцією д-ра екон. наук А. О. Єпіфанова, д-ра екон. наук І.О. Школьник і д-ра екон. наук Ф. Павелки. - Суми: ДВНЗ «УАБС НБУ», 2012. - 258 c.

7. Кльоба Л. Г. Фінансовий супермаркет - інноваційна модель розвитку комерційного банку / Л. Г. Кльоба // Проблеми економіки та управління: [зб. наук. праць] / відповід. редактор Й. М. Петрович. - Львів: Вид-во Львівської політехніки, 2012. - С. 103-110 с.

8. Козьменко О. Трансформування банківської системи України під впливом іноземних фінансових конгломератів / О. Козьменко // Вісник Національного банку України. - 2014. - № 8. - С. 12-18.

9. Ніколаєва А. М., Іщук Л. І. Розвиток фінансово-кредитного бізнесу в умовах фінансової глобалізації / А. Ніколаєва, Л. Іщук // Економічний форум. - 2013. - № 4. - С. 211-218.

10. Офіційний сайт Національного банку України. - Електронний ресурс. - Режим доступу: http://www.bank.gov.ua.

11. Офіційний сайт Національної комісії, що здійснює державне регулювання у сфері ринків фінансових послуг.

- Електронний ресурс. - Режим доступу: https://www.nfp.gov.ua.

12. Офіційний сайт ПАТ «Мегабанк» // Електронний ресурс. - Режим доступу: https://www.megabank.ua/ua.

13. Офіційний сайт ПАТ «ПУМБ» // Електронний ресурс. - Режим доступу: https://www.pumb.ua.

14. Офіційний сайт ПАТ «Таскомбанк» // Електронний ресурс. - Режим доступу: https://tascombank.ua.

15. Офіційний сайт ПАТ АБ «Південний» // Електронний ресурс. - Режим доступу: https://bank.com.ua/ua.

16. Офіційний сайт ПАТ КБ «Приватбанк» // Електронний ресурс. - Режим доступу: https://privatbank.ua.

17. Пасько О. М. Узгодження умов взаємодії банків і страхових компаній / О. М. Пасько // Вісник Університету банківської справи Національного банку України. - 2010. - № 3. - С. 260-263.

18. Посохов І. М. Операційні ризики: управління та основні напрямки зниження / I. Посохов // Вісник економіки транспорту і промисловості. - 2012. - № 37. - Електронний ресурс. - Режим доступу: http://www.uran. donetsk.ua/ masters/2012/iem/miroshnichenko/library/article4.pdf.

19. Пшик Б. І. Фінансово-кредитні відносини в Україні: проблеми становлення, перспективи розвитку, напрями вдосконалення: монографія / Б. І. Пшик. - Інститут регіональних досліджень НАН України. - К.: УБС НБУ, 2011. $-530 \mathrm{c}$.

20. Тимків А. О. Становлення ризик-менеджменту в інвестиційній діяльності комерційних банків в Україні / А. О. Тимків // Наукові записки Національного університету «Острозька академія»: Економіка. - 2011. - Вип. 17. C. 398-404.

21. Фурман В. М. Перспективи створення альянсів страхових компаній і банків в Україні / В. М. Фурман // Вісник НБУ. - 2005. - № 4. - С. 20-22.

\section{REFERENCES}

1. Benoist, G. (2002). Bancassurance: The New Challenges. The Geneva Papers on Risk and Insurance, 27/3, 295-303 [in English].

2. Okeahalam, C. (2008). Does Bancassurance Reduce the Price of Financial Service Products. Journal of Financial Services Research, 33, 147-162 [in English].

3. Paige, F. L. (2007). Bidder returns in bancassurance mergers: Is there evidence of synergy? Journal of Banking \& Finance, 31, 3646-3662 [in English].

4. Bahmet, K. V. (2012). Bankivs'ko-strakhova intehratsiya v zabezpechenni rozvytku finansovoho sektora ekonomiky [Banking and insurance integration in providing development of the financial sector of the economy]. Candidate's thesis. Sumy: SHEE «UAB NBU» [in Ukrainian].

5. Bilorus, O. H., \& Havrylyuk, O. V. (2013). Finansova hlobalizatsiya: paradyhmal'ni zrushennya y ryzyky [Financial globalization: paradigmatic shifts and risks]. Finansy Ukrayiny - Finances of Ukraine, 7, 7-17 [in Ukrainian].

6. Intehratsiyni protsesy na finansovomu rynku Ukrayiny: monohrafiya [Integration processes in the financial market of Ukraine: monograph]. (2012). A. O. Yepifanov, I. O. Shkol'nyk, F. Pavelkf (Eds.). Sumy: SHEE «UAB NBU» [in Ukrainian]. 
7. Kl'oba, L. H. (2012). Finansovyy supermarket - innovatsiyna model' rozvytku komertsiynoho banku [Financial supermarket - innovative model of commercial bank's development]. Problemy ekonomiky ta upravlinnya - Problems of economics and management, 103-110 [in Ukrainian].

8. Koz'menko, O. (2014). Transformuvannya bankivs'koyi systemy Ukrayiny pid vplyvom inozemnykh finansovykh konhlomerativ [Transformation of the Ukrainian banking system under the influence of foreign financial conglomerates]. Visnyk Natsional'noho banku Ukrayiny - Bulletin of the National Bank of Ukraine, 8, 12-18 [in Ukrainian].

9. Nikolayeva, A. M., \& Ishchuk, L. I. (2013). Rozvytok finansovo-kredytnoho biznesu v umovakh finansovoyi hlobalizatsiyi [Development of financial and credit business in the conditions of financial globalization], Ekonomichnyy forum - Economic forum, 4, 211-218 [in Ukrainian].

10. Ofitsiynyy sayt Natsional'noho banku Ukrayiny [Official site of the National Bank of Ukraine]. bank.gov.ua. Retrieved from: http://www.bank.gov.ua. [in Ukrainian].

11. Ofitsiynyy sayt Natsional'noyi komisiyi, shcho zdiysnyuye derzhavne rehulyuvannya u sferi rynkiv finansovykh posluh [Official site of The National Commission for State Regulation of Financial Services Markets]. nfp.gov.ua. Retrieved from: https://www.nfp.gov.ua. [in Ukrainian].

12. Ofitsiynyy sayt PAT «Mehabank» [Official site of the PJSC «Megabank»]. megabank.ua. Retrieved from: https://www.megabank.ua. [in Ukrainian].

13. Ofitsiynyy sayt PAT «PUMB» [Official site of the PJSC «PUMB»]. pumb.ua. Retrieved from: https://www.pumb.ua. [in Ukrainian].

14. Ofitsiynyy sayt PAT «Taskombank» [Official site of the PJSC «Taskombank»]. tascombank.ua. Retrieved from: https://tascombank.ua. [in Ukrainian].

15. Ofitsiynyy sayt PAT AB «Pivdennyy» [Official site of the PJSC CB «Pivdennyy»]. bank.com.ua. Retrieved from: https://bank.com.ua. [in Ukrainian].

16. Ofitsiynyy sayt PAT KB «Pryvatbank» [Official site of the PJSC CB «Privatbank»]. privatbank.ua. Retrieved from: https://privatbank.ua. [in Ukrainian].

17. Pas'ko, O. M. (2010). Uzhodzhennya umov vzayemodiyi bankiv i strakhovykh kompaniy [Harmonization of interaction conditions of banks and insurance companies]. Visnyk Universytetu bankivs'koyi spravy Natsional'noho banku Ukrayiny - Bulletin of the University of Banking of the National Bank of Ukraine, 3, 260-263 [in Ukrainian].

18. Posokhov, I. M. (2012). Operatsiyni ryzyky: upravlinnya ta osnovni napryamky znyzhennya [Operational risks: management and main directions of minimization]. Visnyk ekonomiky transportu i promyslovosti - Bulletin of the Economy of Transport and Industry, $7 . \quad$ Retrieved from: http://www.uran.donetsk.ua/ masters/2012/iem/miroshnichenko/library/article4.pdf. [in Ukrainian].

19. Pshyk, B. I. (2011). Finansovo-kredytni vidnosyny v Ukrayini: problemy stanovlennya, perspektyvy rozvytku, napryamy vdoskonalennya: monohrafiya [Financial and credit relations in Ukraine: problems of formation, prospects of development, directions of perfection: monograph]. K.: UBS NBU [in Ukrainian].

20. Tymkiv, A. O. (2011). Stanovlennya ryzyk-menedzhmentu v investytsiyniy diyal'nosti komertsiynykh bankiv v Ukrayini [Risk management development in the investment activities of commercial banks in Ukraine]. Naukovi zapysky Natsional'noho universytetu «Ostroz'ka akademiya»: Ekonomika - Scientific Notes of the National University of Ostroh Academy: Economics, 17, 398-404 [in Ukrainian].

21. Furman, V. M. (2005). Perspektyvy stvorennya al'yansiv strakhovykh kompaniy i bankiv v Ukrayini [Perspectives of creating alliances of insurance companies and banks in Ukraine]. Visnyk Natsional'noho banku Ukrayiny - Bulletin of the National Bank of Ukraine, 4, 20-22 [in Ukrainian].

Одержано 11.03.2019 